\title{
A N-trágyázás hatása a kukorica levél tápelem-koncentrációjára és a tápelemek közötti kölcsönhatásokra
}

\author{
IZSÁKI ZOLTÁN \\ Szent István Egyetem Víz- és Környezetgazdálkodási Kar, \\ Mezőgazdaságtudományi Intézet, Szarvas
}

\begin{abstract}
Összefoglalás
A kukorica talaj- és növényvizsgálatra alapozott trágyázási szaktanácsadásának fejlesztéséhez 8 éves kísérleti periódusban vizsgáltuk a N-trágyázás $(0,80,160,240 \mathrm{~kg} / \mathrm{ha}$ N) hatását a kukorica szemtermésére, a levél tápelem-koncentrációjára, valamint a tápelemek közötti kölcsönhatásokra. A mútrágyázási tartamkísérletet 1989-ben állítottuk be mélyben karbonátos csernozjom réti talajon, 4-4 N-, P- és K-ellátottsági szinten, teljes kezeléskombinációban, 64 kezeléssel, kétszeresen osztott parcellás elrendezésben. Jelen dolgozatban a 2001-2008 között (a tartamkísérletek 12-19. éveiben) végzett kísérletek N-trágyázási eredményei szerepelnek, melyek alapján az alábbi főbb következtetések tehetôk:

1. A 2,8-3,2\% humusztartalmú csernozjom réti talajon N-trágyázás nélkül 8 év átlagában a talaj 0-60 cm-es rétegének vetés elôtti $\mathrm{NO}_{3}$-N-tartalma $48 \mathrm{~kg} / \mathrm{ha}$, a szemtermés 6,24 t/ha volt. A vizsgált 8 évból csak 3 évben fordult elö, hogy a $80 \mathrm{~kg} / \mathrm{ha}$-nál nagyobb adagú $\mathrm{N}$-trágyázás további szignifikáns terméstöbbletet eredményezett. A szemtermés jelentôsebben a talaj 0-60 cm-es rétegének vetés előtti 80-100 kg/ha $\mathrm{NO}_{3}-\mathrm{N}$ szintjéig növekedett. A $240 \mathrm{~kg} / \mathrm{ha} \mathrm{N}$-adag a termésmaximumhoz képest csökkentette a szemtermést.

2.A N-trágyázás szintjétôl függően a talaj 0-60 cm-es rétegének vetés elôtti $\mathrm{NO}_{3}-\mathrm{N}$ tartalma 30-205 kg/ha között változott a kísérleti ciklus alatt. A kukorica levél Nkoncentrációja a címerhányás kezdetén szoros összefüggést $(\mathrm{r}=0,76)$ mutatott a talaj $\mathrm{NO}_{3}$-N szintjével.

3. A kukorica levél címerhányás kezdetén mért N-koncentrációja és a szemtermés közötti összefüggés alapján a kielégítő N-ellátottsági határérték a maximális szem-
\end{abstract}


termés 95\%-os szintjén 2002-2008 közötti kísérleti években 2,0-3,2\%, míg 2001ben 3,5-4,8\%. Nyolc kísérleti év nagy adatbázisának elemzése azt igazolta, hogy 10-14 t/ha-os szemtermés eléréséhez a kielégítő N-koncentráció határérték a címerhányás kezdetén 2,0-4,0\% közötti értékben határozható meg.

4. A 120-360 mg/kg AL- $\mathrm{P}_{2} \mathrm{O}_{5}$-ellátottságú talajon a N-trágyázás a levél P-koncentrációját 2 évben növelte és 2 évben csökkentette. Ezekben az években a levél N- és P-koncentrációja között a kölcsönhatás kimutatható volt. A levél P-tartalma a címerhányás kezdetén 0,22-0,35\% között változott a N-trágyázás szintjétől és az évjárattól függôen.

5. A $200-465$ mg/kg AL-K 2 O-ellátottságú talajon a N-trágyázás a levél K-koncentrációját érdemben nem befolyásolta. A Ca-tartalom 0,27-0,54\% között változott a kísérleti periódusban, és két évben tapasztaltunk pozitív korrelációt a levél N-és Ca-koncentrációja között. A levél Mg-tartalma 0,18-0,38\% tartományban mozgott, és a két legnagyobb terméshozamú évben érvényesült a N-trágyázás Mg-koncentráció növelő hatása.

6.A levél Mn-koncentrációja minden évben pozitív kölcsönhatást mutatott a növekvő N-tápláltsággal. A N-trágyázás csak a rendkívül száraz évben csökkentette a levél Zn-koncentrációját. Egyes években pozitív kölcsönhatás volt a levél N- és Zn-koncentrációja között. A jobb N-ellátottság a levél Cu-tartalmát 3 évben, a Fetartalmát 2 évben növelte megbízhatóan.

Kulcsszavak: kukorica, N-trágyázás, szemtermés, tápelem-koncentráció, tápelemkölcsönhatás

\title{
The effect of $\mathbf{N}$ fertilisation on the nutrient concentration of maize leaves and the interaction between nutrients
}

\author{
Z. IZSÁKI \\ Szent István University, Faculty of Water and Environmental Management, \\ Institute for Agricultural Sciences, Szarvas
}

\section{Summary}

In order to develop a maize fertilisation consultancy system based on soil and plant analysis, we examined the effect of $\mathrm{N}$ fertilisation $\left(0,80,160,240 \mathrm{~kg} \mathrm{~N} \mathrm{ha}^{-1}\right)$ on the maize grain yield, nutrient concentration and the interactions between nutrients during a 
8-year-long experimental period. The long-term fertilisation experiment was established in 1989 on chernozem meadow soil with a deep calcareous layer. The experiment had four N, P and K levels of supply, the entire treatment combination was performed in a split-split-plot design, using 64 treatments. This study outlines the $\mathrm{N}$ fertilisation results of the experiments performed between 2001-2008 (in the $12^{\text {th }}-19^{\text {th }}$ years of the longterm experiment). The following conclusions can be drawn:

1. Averaged over the 8 years, the pre-sowing $\mathrm{NO}_{3}-\mathrm{N}$ content of the $0-60 \mathrm{~cm}$ layer on the non-fertilised chernozem meadow soil with $2.8-3.2 \%$ humus content was $48 \mathrm{~kg} \mathrm{ha}^{-1}$ and grain yield was $6.24 \mathrm{tha}^{-1}$. $\mathrm{N}$ fertilisation with doses higher than 80 $\mathrm{kg} \mathrm{ha}^{-1}$ resulted in further significant yield surplus only in 3 of the 8 examined years. Grain yield significantly increased until the the pre-sowing 80-100 $\mathrm{kg} \mathrm{ha}^{-1}$ $\mathrm{NO}_{3}-\mathrm{N}$ level of the $0-60 \mathrm{~cm}$ layer of the soil. The $240 \mathrm{~kg} \mathrm{ha}^{-1} \mathrm{~N}$ decreased grain yield in comparison with the maximum yield.

2. Depending on the level of $\mathrm{N}$ fertilisation, the pre-sowing $\mathrm{NO}_{3}-\mathrm{N}$ content of the $0-60 \mathrm{~cm}$ layer of the soil varied between $30-205 \mathrm{~kg} \mathrm{ha}^{-1}$ over the experimental period. The $\mathrm{N}$ concentration of maize leaves showed a close correlation $(\mathrm{r}=0.76)$ with the soil $\mathrm{NO}_{3}-\mathrm{N}$ level at the beginning of tasseling.

3 . Based on the interaction between the $\mathrm{N}$ concentration of maize leaves measured at the beginning of tasseling and grain yield, the satisfactory limit value of $\mathrm{N}$ supply was $2.0-3.2 \%$ between $2002-2008$ at $95 \%$ of the maximum grain yield, while it was $3.5-4.8 \%$ in 2001 . The evaluation of the databases of the eight experimental years showed that in order to reach 10-14 $\mathrm{tha}^{-1}$ yield, the satisfactory limit value of $\mathrm{N}$ concentration has to be between 2.0-4.0\% at the beginning of tasseling.

4. On the soil with $120-360 \mathrm{mg} \mathrm{kg}^{-1} \mathrm{AL}-\mathrm{P}_{2} \mathrm{O}_{5}$ supply, $\mathrm{N}$ fertilisation increased the $\mathrm{P}$ concentration of leaves in two years and also decreased in other two years. During these years, interaction was shown between the $\mathrm{N}$ and $\mathrm{P}$ concentrations of leaves. The P content of leaves was between $0.22-0.35 \%$ at the beginning of tasseling, depending on the level of $\mathrm{N}$ fertilisation and the crop year.

5. On the soil with $200-465 \mathrm{mg} \mathrm{kg}^{-1} \mathrm{AL}-\mathrm{K}_{2} \mathrm{O}$ supply, $\mathrm{N}$ fertilisation did not significantly affect the $\mathrm{K}$ concentration of leaves. The Ca content was between $0.27-0.54 \%$ over the experimental period. The Mg content of leaves was between $0.18-0.38 \%$ and the $\mathrm{Mg}$ concentration increasing effect of $\mathrm{N}$ fertilisation was observed in the two years which showed the highest yields.

6. The Mn concentration of leaves showed positive interactions every year with an increasing level of $\mathrm{N}$ nutrition. The $\mathrm{N}$ fertilisation decreased the $\mathrm{Zn}$ concentration of leaves only in especially dry years. In certain years, there was a positive correlation 
between the $\mathrm{N}$ an $\mathrm{Zn}$ concentration of leaves. The more favourable level of $\mathrm{N}$ supply significantly increased the leaf $\mathrm{Cu}$ content in 3 years and its Fe content in 2 years.

Key words: maize, $\mathrm{N}$ fertilisation, nutrient concentration, nutrient interaction

\title{
Влияние $\mathrm{N}$ удобрения на концентрацию питательных эле- ментов кукурузного листа и на взаимовлияния между пи- тательными элементами
}

\author{
3. ИЖАКИ \\ Факультет Водо-и Экохозяйства Университета им. Св.Иштвана, \\ Институт Сельскохозяйственных наук, Сарваш
}

\begin{abstract}
Резюме
Для развития профессионального консультирования применения удобрений, основанного на исследованиях почвы и растений кукурузы, в 8-и летнем опытном периоде исследовали влияние удобрения $\mathrm{N}\left(0,80,160,240 \mathrm{~kg} \mathrm{~N} \mathrm{ha}^{-1}\right)$ на урожай зерна кукурузы, на концентрацию питательных элементов листа, а также на влияния друг на друга питательных элементов. Продолжительный опыт искусственного удобрения установили в 1989 году на карбонатной, в глубине чернозёмной луговой почве, на 4 уровнях обеспечения N, Р и K, в полной комбинации обработок, с 64 обработками, в дважды разделённом расположении парцелл. В данной работе показаны результаты проведенных опытов внесения удобрений N в 2001-2008 годы (12-19 годы продолжительного опыта),на основании которых можно сделать следующие выводы:

1. На чернозёмной луговой почве с содержанием гумуса $2,8-3,2 \%$ без удобрения $\mathrm{N}$, за 8 лет в среднем, в слое почвы 0-60 cm до посева содержание $\mathrm{NO}_{3}-\mathrm{N}$ было $48 \mathrm{~kg} / \mathrm{ha}$, а урожай зерна был 6,24 t/ha. За восемь лет исследований только в 3 -ёх годах встретилось, что при дозе N удобрения более $80 \mathrm{~kg} / \mathrm{ha}$ было дальнейшее значительное увеличение урожая. Урожай зерна более значительно увеличился при содержании 0-60 cm слоя почвы до посева до уровня 80-100 kg/ha NO $3-\mathrm{N}$. Доза N $240 \mathrm{~kg} / \mathrm{ha}$ по сравнению с максимумом урожая уменьшила урожай зерна.
\end{abstract}


2. В зависимости от уровня удобрения $\mathrm{N}$ содержание $\mathrm{NO}_{3}-\mathrm{N}$ в почвенном слое 0-60 cm до посева изменялось в количестве 30-205 kg/ha за время опыта. Концентрация $\mathrm{N}$ кукурузного листа в начале вымётывания метёлок показала тесную связь $(\mathrm{r}=0,76)$ с уровнем $\mathrm{NO}_{3}-\mathrm{N}$ почвы.

3. На основании взаимосвязи измеренной концентрации $\mathrm{N}$ кукурузного листа в начале выбрасывания метёлок и урожаем зерна, удовлетворительная предельная величина обеспеченности $\mathrm{N}$ на уровне $95 \%$ максимального урожая зерна за 2002-2008 годы опыта была 2,0-3,2\%, и в 2001 году 3,5-4,8\%. Анализ большой базы данных восьми лет опытов подтверждает то, что для достижения урожая зерна 10-14 t/ha удовлетворительный лимит концентрации $\mathrm{N}$ в начале выбрасывания метёлок можно определить в рамках показателей 2,0-4,0\%.

4. На обеспеченной $120-360 \mathrm{mg} / \mathrm{kg} \mathrm{AL}-\mathrm{P}_{2} \mathrm{O}_{5}$ почве удобрение $\mathrm{N}$ увеличило концентрацию Р листа в 2-ух годах, и уменьшило в 2-ух годах. В эти годы взаимовлияние концентрации $\mathrm{N}$ и Р листа было доказуемо. Содержание Р листом в начале вымётывния метёлок изменялось в пределах 0,22-0,35\% в зависимости от уровня удобрения $\mathrm{N}$ и от года выращивания.

5. На почве, обеспеченной 200-465 mg/ $\mathrm{kg}$ AL-K 2 O, удобрение $\mathrm{N}$ не повлияло существенно на концентрацию К листа. Содержание Са изменялось в рамках 0,27-0,54\% в период опыта, и в двух годах обнаружили позитивную корреляцию между концентрацией в листьях $\mathrm{N}$ и Са. Содержание $\mathrm{Mg}$ листом изменялось в пределах $0,18-0,38 \%$, и в двух самых урожайных годах проявилось увеличивающееся влияние удобрение $\mathrm{N}$ на концентрацию $\mathrm{Mg}$.

6. Концентрация листом Mn в каждом году показало позитивное взаимодействие с растущей обеспеченностью N. Удобрение N только в крайне засушливый год уменьшило концентрацию Zn листа. В другие годы было позитивное взаимовлияние между концентрацией $\mathrm{N}$ и $\mathrm{Zn}$ листа. Лучшая обеспеченность $\mathrm{N}$ подтверждаемо увеличило содержание $\mathrm{Cu}$ листа в трёх годах, содержание $\mathrm{Fe}$ в двух годах также увеличило.

Ключевые слова: кукуруза, N удобрение, урожай зерна, концентрация питательного элемента, взаимовлияние питательного элемента 


\section{Bevezetés}

Egy növény trágyaigényét bármilyen egzaktan kidolgozott, jól kalibrált módszerrel határozzuk is meg, előfordulhat, hogy a tenyészidő alatt valamely tápelem abszolút vagy relatív hiánya illetve túlsúlya terméscsökkenést vagy minôségromlást okozhat. Mindez arra vezethetô vissza, hogy az alkalmazott trágyaszükséglet becslési módszer nem képes figyelembe venni a tenyészidő alatt a talaj változó tápanyag-szolgáltatását valamint a tápelemek kölcsönhatásának, a növény aktív szerepének és az idôjárás változásainak befolyását a növény tápelem-felvételére. A növény növekedése, terméshozama és minôsége az ásványi elemek koncentrációjának is függvénye, melyet meghatározott növényi szervek a fejlődés egyes stádiumaiban tükröznek. Egy-egy növényi szerv ásványi összetétele tükrözi mindazon tényezők befolyását, amelyek a fejlődés adott időpontjáig hatottak a növény tápelem-felvételére (Bergmann és Neubert 1976, Lemaire 1997, Smith és Loneragan 1997). Ezért a korszerú trágyázási szaktanácsadási rendszer a talajvizsgálatok mellett nem nélkülözheti a diagnosztikai célú növényanalízist. Bár a tenyészidőben végzett növényanalízis trágyaadag meghatározására nem alkalmas, de felhasználható a növénytáplálás számos területén: a növény tápláltsági állapotának megállapítására; talajvizsgálatok, tápanyag-ellátottság és trágyázási gyakorlat ellenôrzésére; tápelemek közötti kölcsönhatások kimutatására; rejtett táplálkozási zavarok felderítésére, látható hiány- vagy túlsúlytünet azonosítására; fejlődési rendellenességek okainak feltárására; terméshozam és minôség elôrejelzésére (Kádár 1992, 2008, Izsáki 2000).

A kukorica tápláltsági állapotának megítéléséhez több szerző (Chapman 1967, Jones 1967, Bergmann és Neubert 1976, Kádár és Elek 1980, Kádár 1992, Plénet és Cruz 1997, Csathó 1998, Izsáki 2004, 2009, 2010a) is közöl tápelem-koncentráció határértékeket egy-egy fejlődési stádiumra (4-6 leveles állapot, címerhányás kezdete), illetve növényi részre (teljes földfeletti növény, levél) a hiányos, a kielégítő és a túlzott tápanyag-ellátottságra. E publikált határértékek egyes tápelemek esetében jó egyezóséget, míg más tápelemek vonatkozásában jelentősebb eltérést mutatnak. A genetikai előrehaladás, a nemesítés és az agrotechnika permanens fejlődésének eredményeként a kukorica potenciális termôképessége, terméshozama növekvô trendet mutat. Így különösen fontos, hogy a nagy terméshozamokhoz tartozó tápelem-koncentráció határértékeket ellenôrizzük, pontosítsuk, illetve meghatározzuk. Erre jó lehetôséget kínálnak azok a tartamkísérletek, ahol a talaj tápelem-ellátottsága tág intervallumban változik. 
A dolgozat célja, hogy kukorica mútrágyázási tartamkísérlet nyolc éves diagnosztikai célú növényanalízisének eredményei alapján ismertesse a N-trágyázás hatását a kukorica tápláltsági állapotára, a tápelemek közötti kölcsönhatásokra, a N-tápláltság és a terméshozam összefüggésére.

\section{Anyag és módszer}

A mútrágyázási tartamkísérletet a Szent István Egyetem Víz- és Környezetgazdálkodási Kar Növénytermesztéstani Tanszéke Kísérleti Telepén, Szarvason állítottuk be 1989-ben. A kísérleti terület talaja mélyben karbonátos csernozjom réti talaj, a humuszos réteg vastagsága $85-100 \mathrm{~cm}$, a múvelt réteg pH(KCl)-ja 5,0-5,2, humusztartalma 2,8-3,2\%, $\mathrm{CaCO}_{3}$-ot nem tartalmaz, kötöttsége (KA) 50, agyagtartalma $32 \%$.

A kísérlet beállítása előtt 1989 ószén az AL- $\mathrm{P}_{2} \mathrm{O}_{5} 156 \mathrm{mg} / \mathrm{kg}$, az AL-K $20322 \mathrm{mg} / \mathrm{kg}$, AL-Na 212 mg/kg, a KCI-Mg 765 mg/kg, az EDTA-Mn 386 mg/kg, az EDTA-Cu $5,4 \mathrm{mg} / \mathrm{kg}$, és az EDTA-Zn 3,0 mg/kg volt a kísérleti terület átlagában. A MÉM NAK (1979) által elfogadott módszerek és határértékek alapján a talaj ellátottsága Pból, K-ból és Cu-ből jó, Mg-ból és Mn-ból magas, még Zn-ból kielégítő volt. A 2001-es talajvizsgálatok szerint a talaj múvelt rétegének Mg-, Mn-, Cu- és Zntartalma ugyanabba az ellátottsági kategóriába esett, mint a kísérlet beállításakor. A talajvíz átlagos mélysége $300-350 \mathrm{~cm}$.

A trágyakezeléseket 4-4 N-, P- és K-szinten alakítottuk ki, teljes kombinációban, azaz 64 kezeléssel, kétszeresen osztott parcellás elrendezésben, három ismétlésben. A kísérletben alkalmazott trágyakezelések, nitrogénból: $\mathrm{N}_{0}=0 ; \mathrm{N}_{1}=80 ; \mathrm{N}_{2}=160$; $\mathrm{N}_{3}=240 \mathrm{~kg} / \mathrm{ha} /$ év $\mathrm{N}$, foszforból $\left(\mathrm{P}_{2} \mathrm{O}_{5}\right): \mathrm{P}_{0}=0 ; \mathrm{P}_{1}=100 \mathrm{~kg} / \mathrm{ha} /$ év; $\mathrm{P}_{2}=500 \mathrm{~kg} / \mathrm{ha}$ 1989-ben, 1993-ban és 2001-ben, $\mathrm{P}_{3}=1000 \mathrm{~kg} / \mathrm{ha} 1989$-ben, 1993-ban és 2001-ben; káliumból $\left(\mathrm{K}_{2} \mathrm{O}\right)$ : $\mathrm{K}_{0}=0 ; \mathrm{K}_{1}=300 \mathrm{~kg} / \mathrm{ha} /$ év 1989-1992, $100 \mathrm{~kg} / \mathrm{ha} /$ év 1993-tól; $\mathrm{K}_{2}=600 \mathrm{~kg} / \mathrm{ha} 1989-$ ben és 2001-ben, $1000 \mathrm{~kg} / \mathrm{ha} 1993-\mathrm{ban} ; \mathrm{K}_{3}=1200 \mathrm{~kg} / \mathrm{ha} 1989-\mathrm{ben}$ és 2001-ben, $1500 \mathrm{~kg} / \mathrm{ha}$ 1993-ban. A nagyadagú P és K feltöltő trágyázás célja az volt, hogy jól elkülönülő ellátottsági szinteket alakítsunk ki a talajban a tápláltsági szituációk tanulmányozására. A 2001-2008-as kísérleti ciklus alatt a trágyázási kezelésektől függóen a P-ellátottság 120-360 mg/kg AL- $\mathrm{P}_{2} \mathrm{O}_{5}$, és a K-ellátottság 200$465 \mathrm{mg} / \mathrm{kg} \mathrm{AL}-\mathrm{K}_{2} \mathrm{O}$ között változott. A nitrogént ammóniumnitrát (34\%), a foszfort szuperfoszfát (18\%) és a káliumot kálisó (40-60\%) formájában ôsszel juttattuk ki. A kísérletben évente 4 növény szerepelt kiterített vetésforgóban, $4 \times 192$ db parcellán, ahol a másodrendú alparcellák mérete 4×5=20 m² volt. 
A kukorica kísérleteket 1994-től végezzük. Jelen dolgozatban a 2001-2008 között FAO 300-as hibriddel végzett kísérletek eredményei szerepelnek. A kukorica elôveteménye 2001-2006 között silócirok és 2007-2008 között ôszi árpa volt. A vetést $75 \mathrm{~cm}$-es sortávolságra, 75 ezer csíra/ha-ral végeztük.

Az egyes kísérleti évek vízellátottságát a tenyészidő alatt lehullott csapadék mennyiségével jellemezve megállapítható, hogy a legkedvezőbb csapadék eloszlású és vízellátottságú évek 2001, 2005, 2006 és 2008; kevésbé jó csapadék elosztású, de a sokévi átlagot meghaladó tenyészidő alatti vízellátottságú évek 2002, 2004; száraz, aszályos évek 2003 és 2007 voltak (1. táblázat).

1. táblázat. A csapadék mennyisége és eloszlása a vizsgálati időszak alatt, mm (Szarvas 2000-2008)

\begin{tabular}{|c|c|c|c|}
\hline $\begin{array}{l}\text { Év } \\
(1)\end{array}$ & $\begin{array}{c}\text { Nyári félév } \\
\text { (IV-IX.) } \\
\text { (2) }\end{array}$ & $\begin{array}{c}\text { Téli félév } \\
\text { (X-III.) } \\
(3)\end{array}$ & $\begin{array}{c}\text { Évi összes } \\
\text { (4) }\end{array}$ \\
\hline Átlag 1901-1975 (5) & 313 & 225 & 538 \\
\hline 2000 & 216 & 291 & 339 \\
\hline 2001 & 416 & 190 & 612 \\
\hline 2002 & 353 & 118 & 489 \\
\hline 2003 & 96 & 213 & 350 \\
\hline 2004 & 389 & 252 & 659 \\
\hline 2005 & 518 & 268 & 721 \\
\hline 2006 & 364 & 204 & 537 \\
\hline 2007 & 317 & 159 & 550 \\
\hline 2008 & 375 & 200 & 464 \\
\hline Átlag 2000-2008 (6) & 338 & 222 & 525 \\
\hline
\end{tabular}

Table 1. Quantity and distribution of rainfall during the examination period, $\mathrm{mm}$ (Szarvas 20002008). (1) Year, (2) Summer period (months IV-IX), (3) Winter period (months X-III), (4) Year total, (5) Average 1901-1975, (6) Average 2000-2008.

A talaj tápelem-vizsgálatokat évente, ósszel az elővetemény betakarítása után a 0-60 cm-es talajrétegbool vett mintákból végeztük el. A talaj $\mathrm{P}_{2} \mathrm{O}_{5}$ - és $\mathrm{K}_{2} \mathrm{O}$ tartalmát AL-módszerrel határoztuk meg, és az eredmények értékelésekor a talaj P- és K-ellátottságának jellemzésére a szántott réteg értékeit használjuk. A talaj ásványi nitrogén-tartalmát $\left(\mathrm{NO}_{3}-\mathrm{NO}_{2}-\mathrm{NH}_{4}-\mathrm{N}\right) 1 \mathrm{~mol} \cdot \mathrm{dm}^{-3} \mathrm{KCI}$-os kivonatból fotometriás módszerrel, ôsszel és tavasszal a vetést megelôzốen határoztuk 
meg a 0-60 cm-es talajrétegből. A 2001 és 2008 közötti kísérleti periódus tavaszi, vetés elôtti $\mathrm{NO}_{3}-\mathrm{N}$-tartalom eredményeit a 2. táblázat tartalmazza $\mathrm{N}$-trágyázási szintenként.

2. táblázat. A talaj O-60 cm-es rétegének vetés elootti $\mathrm{NO}_{3}$-N-tartalma a kísérleti években (Szarvas 2001-2008)

\begin{tabular}{|c|c|c|c|c|}
\hline & \multicolumn{4}{|c|}{$\begin{array}{c}\mathrm{N} \text {-adag }(\mathrm{kg} / \mathrm{ha}) \\
(2)\end{array}$} \\
\hline & 0 & 80 & 160 & 240 \\
\hline & \multicolumn{4}{|c|}{$\begin{array}{c}\mathrm{NO}_{3}-\mathrm{N}(\mathrm{kg} / \mathrm{ha}) 0-60 \mathrm{~cm} \text {-es talajrétegben } \\
\text { (3) }\end{array}$} \\
\hline 2001 & 38 & 80 & 131 & 148 \\
\hline 2002 & 60 & 85 & 180 & 205 \\
\hline 2003 & 39 & 55 & 61 & 77 \\
\hline 2004 & 64 & 96 & 133 & 191 \\
\hline 2005 & 28 & 49 & 85 & 97 \\
\hline 2006 & 41 & 59 & 91 & 122 \\
\hline 2007 & 56 & 102 & 133 & 172 \\
\hline 2008 & 58 & 96 & 143 & 194 \\
\hline
\end{tabular}

Table 2. The $\mathrm{NO}_{3}$ - $\mathrm{N}$ content of the 0-60 cm layer of soil in the years of experiment (Szarvas 20012008). (1) Year, (2) $\mathrm{N}$ dose $\left(\mathrm{kg} \mathrm{ha}^{-1}\right),(3) \mathrm{NO}_{3}-\mathrm{N}\left(\mathrm{kg} \mathrm{ha}^{-1}\right)$ in the $0-60 \mathrm{~cm}$ soil layer.

A kukorica tápláltsági állapotának vizsgálatához parcellánként 15 növényrôl a csôvel szembeni leveleket gyújtöttük be a címerhányás kezdetén. A levélmintákat 8 kísérleti évben (2001-2008) vizsgáltuk a következó tápelemekre: N, P, K, Ca, Mg, Fe, Mn, Zn és Cu. A N, P és K meghatározására a minták kénsavas, majd hidrogénperoxidos roncsolása után a $\mathrm{N}$ és $\mathrm{P}$ vonatkozásában fotometriásan, a K esetében lángfotométerrel történt. A Ca, Mg, Fe, Mn, Zn és Cu tartalmat sósavas ( $2 \mathrm{~mol} \cdot \mathrm{dm}^{-3} \mathrm{KCl}$ ) hidrolízis után atomabszorpciós (AAS) készülékkel határoztuk meg. A kukorica levél tápelem-koncentráció értékei szárazanyagra vonatkoznak. A N-trágyázás tápelem-koncentrációra, tápelemek közötti kölcsönhatásokra és terméshozamra gyakorolt hatásának elemzésekor csak a N-fóhatások eredményei kerülnek bemutatásra a P- és K-kezelések átlagában. A kukorica szemtermése szárazanyagban van megadva. A kukorica Ntápláltsági határértékének megállapításához a tényleges termést (t/ha) illetve 
a relatív szemtermést (a maximális szemtermés \%-ában kifejezett termés) és a levél N-koncentráció értékeit koordináta rendszerben grafikusan ábrázoltuk és a ponthalmazt burkoló görbével határoltuk. A kielégítő N-ellátottság N-koncentráció határértékét a kukorica maximális szemtermésének 95\%-os szintjére határoztuk meg.

\section{Kísérleti eredmények és következtetések}

\section{Szemtermés}

Diagnosztikai célú növényanalízist a kukorica mútrágyázási tartamkísérletek 2001 és 2008 közötti idôszakában, a 12-19. kísérleti években végeztünk. A növényanalízis eredményeinek értelmezéséhez a N-ellátottság (2. táblázat) szemtermés hozamra gyakorolt hatását a 3. táblázat alapján értékelhetjük.

3. táblázat. A N-trágyázás hatása a kukorica szemtermésére, t/ha szárazanyag (Szarvas 2001-2008)

\begin{tabular}{|c|c|c|c|c|c|c|}
\hline \multirow{3}{*}{$\begin{array}{l}\text { Év } \\
\text { (1) }\end{array}$} & \multicolumn{4}{|c|}{ N-adag (kg/ha) } & \multirow{3}{*}{$\begin{array}{l}\mathrm{SzD}_{5 \%} \\
(3)\end{array}$} & \multirow{3}{*}{$\begin{array}{l}\text { Átlag } \\
(4)\end{array}$} \\
\hline & 0 & 80 & 160 & 240 & & \\
\hline & \multicolumn{4}{|c|}{$\begin{array}{l}\text { Szemtermés (t/ha) } \\
(5)\end{array}$} & & \\
\hline 2001 & 9,52 & 11,00 & 11,11 & 11,00 & 0,27 & 10,65 \\
\hline 2002 & 6,08 & 6,97 & 6,49 & 6,12 & 0,20 & 6,41 \\
\hline 2003 & 2,71 & 3,29 & 3,33 & 3,10 & 0,14 & 3,10 \\
\hline 2004 & 6,72 & 7,37 & 7,46 & 7,04 & 0,15 & 7,14 \\
\hline 2005 & 6,97 & 10,13 & 11,98 & 12,17 & 0,34 & 10,31 \\
\hline 2006 & 5,92 & 7,86 & 9,08 & 9,67 & 0,17 & 8,13 \\
\hline 2007 & 5,13 & 5,86 & 5,97 & 5,48 & 0,21 & 5,61 \\
\hline 2008 & 9,05 & 11,46 & 12,25 & 11,85 & 0,38 & 11,15 \\
\hline Átlag (4) & 6,24 & 7,59 & 8,04 & 7,88 & - & 7,43 \\
\hline
\end{tabular}

Table 3. The effect of $\mathrm{N}$ fertilisation on the grain yield of maize, $\mathrm{t}$ ha ${ }^{-1}$ dry matter (Szarvas 20012008). (1) Year, (2) N dose (kg ha-1), (3) $\mathrm{LSD}_{5 \%}$, (4) Mean, (5) Grain yield (t ha-1). 
A vizsgált 8 kísérleti évben $N$-trágyázás nélkül a talaj 0-60 cm-es rétegének vetés elôtti $\mathrm{NO}_{3}$-N-tartalma 28-64 kg/ha és a szemtermés 2,71-9,52 t/ha között változott. Az $\mathrm{N}_{0}$-szinten átlagosan elért 6,24 t/ha szemtermés arról tanúskodik, hogy a 2,8-3,2\% humusztartalmú talaj jó N-szolgáltatású. E mútrágyázási tartamkísérletek 18 éves tápelem-forgalmi vizsgálatai is ezt igazolják, mert N-trágyázás nélkül a talaj átlagos évi N-szolgáltatása $126 \mathrm{~kg} /$ ha volt (Izsáki 2010b). A N-trágyázás, a jobb N-ellátottság minden évben szignifikáns termésnövekedést eredményezett. A vizsgált nyolc évboól öt évben a $80 \mathrm{~kg}$ /ha-nál nagyobb adagú N-trágyázás további szignifikáns hozamnövekedéssel nem járt együtt. Két évben volt kimutatható a $160 \mathrm{~kg} / \mathrm{ha}$-, egy évben a $240 \mathrm{~kg} / \mathrm{ha}$ N-trágyázás megbízható termésnövelô hatása a $80 \mathrm{~kg} / \mathrm{ha} \mathrm{N-trágyázáshoz} \mathrm{képest.} \mathrm{A} \mathrm{nyolc} \mathrm{évből} \mathrm{hét} \mathrm{évben} \mathrm{a} 240 \mathrm{~kg} / \mathrm{ha}$ adagú N-trágyázás a termésmaximumhoz viszonyítva csökkentette a szemtermést. Korábbi vizsgálatainkkal (Izsáki 2008a) egyezôen az évek többségében a szemtermés jelentôsebben a talaj 0-60 cm-es rétegének vetés elootti $80-100 \mathrm{~kg} / \mathrm{ha}$ $\mathrm{NO}_{3}$-N szintjéig növekedett. Az évenkénti terméshozamokat összehasonlítva megállapítható, hogy az évjárat általában nagyobb terméskülönbséget okozott, mint egy adott éven belül az eltérô N-ellátottsági szintek. Hasonló eredményekrôl számol be Berzsenyi (1993), Nagy és Huzsvai (1995), Sárvári és Szabó (1998), Nagy (1995, 2007), Lente és Pepó (2009) és Pepó (2009).

\section{Tápelem-koncentráció és-kölcsönhatás}

Kísérletünkben vizsgáltuk a N-trágyázás hatását a talaj 0-60 cm-es rétegének vetés elótti $\mathrm{NO}_{3}$ - $\mathrm{N}$-tartalmára, valamint a talaj $\mathrm{NO}_{3}-\mathrm{N}$ készletének és a kukorica levél N-koncentrációjának összefüggését (1. ábra). A N-trágyázás szintjétől függốen a talaj 0-60 cm-es rétegének vetés előtti $\mathrm{NO}_{3}$-N-tartalma 30 és $205 \mathrm{~kg} / \mathrm{ha}$ között változott a kísérleti ciklus alatt. A kukorica levél N-koncentrációja a címerhányás kezdetén szoros pozitív ( $\mathrm{r}=0,76)$ összefüggést mutatott a talaj $\mathrm{NO}_{3}-\mathrm{N}$ szintjével. Vagyis, a kukorica N-tápláltsága, a levél N\%-a jól tükrözi a talaj N-ellátottságát és szolgáltatását.

A N-trágyázás hatását a kukorica levél tápelem-koncentrációjára a 4. és 5. táblázatok adatai alapján értékelhetjük. Minden kísérleti évben kimutatható volt, hogy a jobb N-ellátottság a levél N-koncentrációját fokozatosan növelte. Összehasonlítva a kukorica levél címerhányás kezdetén mért évenkénti N-tartalom értékeit kitúnik, hogy 2001-ben kiugróan magas a N\% a többi évhez viszonyítva. A 2002-2008 közötti N-koncentráció értékek között csak viszonylag kisebb különbségek mutathatók ki ugyanazon N-trágyázási szinten, annak ellenére, 
hogy vízellátottságban és hőmérsékleti viszonyokban jelentős eltérések voltak az évek között.

1. ábra. Összefüggés a talaj $\mathrm{O}-60 \mathrm{~cm}$-es rétege vetés elôtti $\mathrm{NO}_{3}-\mathrm{N}$ tartalma és a kukorica levél N-koncentrációja között

(Szarvas 2002-2008)

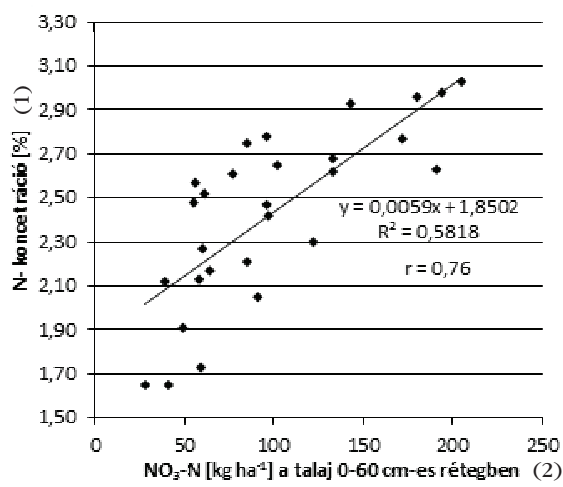

Figure 1. Correlation between the pre-sowing $\mathrm{NO}_{3}-\mathrm{N}$ content of the $0-60 \mathrm{~cm}$ of the soil and the $\mathrm{N}$ concentration of maize leaves (Szarvas 2002-2008). (1) $\mathrm{N}$ concentration [\%], (2) $\mathrm{NO}_{3}-\mathrm{N}$ [ $\left.\mathrm{kg} \mathrm{ha}^{-1}\right]$ in the $0-60 \mathrm{~cm}$ layer of the soil.

A kísérleti adatok szerint a N-ellátottságbeli különbségek jól tükrözôdnek mind a terméshozamban, mind a levél N-koncentrációjában. Szoros összefüggést tudtunk kimutatni minden évben a levél N-koncentrációja és a szemtermés között. Ezen összefüggések alapján a kukorica N-tápláltsági határértékének megállapításához a szemtermést és a levél N-koncentráció értékeit koordináta rendszerben grafikusan ábrázoltuk és a ponthalmazt burkoló görbével határoltuk. A burkoló görbe mentén elhelyezkedó értékek azt az esetet reprezentálják, amikor a termést befolyásoló tényezők optimumban vannak és a hozamot csak a N-koncentráció befolyásolja. A burkoló görbe alatt elhelyezkedó értékek esetében egyes termés-meghatározó tényezók nincsenek optimumban és a termésszint nemcsak a N-tápláltságtól függ. Minél nagyobb termésszintre határozzuk meg a tápelem-ellátottsági optimumot annál szúkebb annak intervalluma, és minél kisebb hozamra annál tágabb. 
4. táblázat. A N-trágyázás hatása a kukorica levél tápelem-koncentrációjára a címerhányás kezdetén

(Szarvas 2001-2004)

\begin{tabular}{|c|c|c|c|c|c|c|c|c|c|}
\hline \multirow{3}{*}{$\begin{array}{l}\text { N-adag } \\
\mathrm{kg} / \mathrm{ha} \\
\text { (1) }\end{array}$} & \multicolumn{9}{|c|}{$\begin{array}{c}\text { Tápelem-koncentráció } \\
\text { (2) }\end{array}$} \\
\hline & $\mathbf{N}$ & $\mathbf{P}$ & $\mathrm{K}$ & $\mathrm{Ca}$ & $\mathrm{Mg}$ & $\mathrm{Mn}$ & $\mathrm{Zn}$ & $\mathrm{Cu}$ & $\mathrm{Fe}$ \\
\hline & \multicolumn{6}{|c|}{$\%$} & \multicolumn{3}{|c|}{$\mathrm{mg} / \mathrm{kg}$} \\
\hline \multicolumn{10}{|c|}{2001} \\
\hline 0 & 3,52 & 0,34 & 2,02 & 0,27 & 0,19 & 44 & 17,9 & 3,6 & 82 \\
\hline 80 & 3,91 & 0,35 & 2,07 & 0,30 & 0,19 & 53 & 18,5 & 3,8 & 93 \\
\hline 160 & 4,26 & 0,35 & 2,07 & 0,28 & 0,20 & 59 & 17,6 & 3,4 & 87 \\
\hline 240 & 4,35 & 0,35 & 2,07 & 0,31 & 0,18 & 77 & 19,7 & 3,5 & 93 \\
\hline $\mathrm{SzD}_{5 \%}(3)$ & 0,54 & NS & NS & NS & NS & 22 & NS & NS & NS \\
\hline Átlag (4) & 4,01 & 0,35 & 2,06 & 0,29 & 0,19 & 58 & 18,4 & 3,6 & 89 \\
\hline \multicolumn{10}{|c|}{2002} \\
\hline 0 & 2,27 & 0,28 & 2,42 & 0,50 & 0,32 & 88 & 17,4 & 4,6 & 205 \\
\hline 80 & 2,75 & 0,30 & 2,48 & 0,49 & 0,32 & 110 & 17,9 & 5,1 & 216 \\
\hline 160 & 2,96 & 0,31 & 2,45 & 0,51 & 0,32 & 134 & 19,7 & 5,2 & 218 \\
\hline 240 & 3,03 & 0,32 & 2,55 & 0,50 & 0,32 & 147 & 22,3 & 5,2 & 225 \\
\hline $\mathrm{SzD}_{5 \%}(3)$ & 0,16 & 0,02 & NS & NS & NS & 18 & 3,8 & NS & NS \\
\hline Átlag (4) & 2,75 & 0,30 & 2,47 & 0,50 & 0,32 & 120 & 19,3 & 5,0 & 216 \\
\hline \multicolumn{10}{|c|}{2003} \\
\hline 0 & 2,12 & 0,34 & 1,73 & 0,51 & 0,36 & 101 & 31,0 & 7,1 & 169 \\
\hline 80 & 2,48 & 0,33 & 1,77 & 0,54 & 0,35 & 123 & 27,0 & 7,5 & 186 \\
\hline 160 & 2,52 & 0,33 & 1,81 & 0,52 & 0,37 & 131 & 26,8 & 7,5 & 194 \\
\hline 240 & 2,61 & 0,34 & 1,88 & 0,52 & 0,36 & 148 & 27,2 & 7,6 & 183 \\
\hline $\mathrm{SzD}_{5 \%}(3)$ & 0,20 & NS & NS & NS & NS & 10 & 2,2 & NS & NS \\
\hline Átlag (4) & 2,43 & 0,33 & 1,79 & 0,52 & 0,36 & 126 & 28,0 & 7,4 & 183 \\
\hline \multicolumn{10}{|c|}{2004} \\
\hline 0 & 2,17 & 0,30 & 1,88 & 0,44 & 0,30 & 106 & 20,9 & 5,6 & 103 \\
\hline 80 & 2,47 & 0,31 & 1,92 & 0,44 & 0,28 & 127 & 20,3 & 5,7 & 111 \\
\hline 160 & 2,62 & 0,32 & 1,92 & 0,46 & 0,30 & 148 & 19,8 & 5,7 & 120 \\
\hline 240 & 2,63 & 0,32 & 1,97 & 0,46 & 0,30 & 159 & 21,0 & 5,7 & 117 \\
\hline $\mathrm{SzD}_{5 \%}$ (3) & 0,17 & NS & NS & NS & NS & 34 & NS & NS & NS \\
\hline Átlag (4) & 2,42 & 0,31 & 1,92 & 0,45 & 0,29 & 135 & 20,5 & 5,7 & 113 \\
\hline
\end{tabular}

Table 4. The effect of $\mathrm{N}$ fertilisation on the nutrient concentration of maize leaves at the beginning of tasseling (Szarvas 2001-2004). (1) N dose ( $\mathrm{kg} \mathrm{ha}^{-1}$ ), (2) Nutrient concentration, (3) LSD $\mathrm{L}_{5 \%}$, (4) Mean. 
5. táblázat. A N-trágyázás hatása a kukorica levél tápelem-koncentrációjára a címerhányás kezdetén

(Szarvas 2005-2008)

\begin{tabular}{|c|c|c|c|c|c|c|c|c|c|}
\hline \multirow{3}{*}{$\begin{array}{c}\text { N-adag } \\
\mathrm{kg} / \mathrm{ha} \\
\text { (1) }\end{array}$} & \multicolumn{9}{|c|}{$\begin{array}{c}\text { Tápelem-koncentráciṕ } \\
\text { (2) }\end{array}$} \\
\hline & $\mathrm{N}$ & $\mathrm{P}$ & $\mathrm{K}$ & $\mathrm{Ca}$ & $\mathrm{Mg}$ & Mn & $\mathrm{Zn}$ & $\mathrm{Cu}$ & $\mathrm{Fe}$ \\
\hline & \multicolumn{5}{|c|}{$\%$} & \multicolumn{4}{|c|}{$\mathrm{mg} / \mathrm{kg}$} \\
\hline \multicolumn{10}{|c|}{2005} \\
\hline 0 & 1,65 & 0,30 & 1,78 & 0,29 & 0,19 & 79 & 15,3 & 6,0 & 130 \\
\hline 80 & 1,91 & 0,28 & 1,81 & 0,34 & 0,21 & 87 & 15,3 & 7,3 & 132 \\
\hline 160 & 2,21 & 0,27 & 1,80 & 0,37 & 0,21 & 101 & 15,1 & 8,6 & 135 \\
\hline 240 & 2,42 & 0,27 & 1,77 & 0,40 & 0,24 & 116 & 15,6 & 8,4 & 146 \\
\hline $\mathrm{SzD}_{5 \%}(3)$ & 0,15 & 0,01 & NS & 0,04 & 0,02 & 14 & NS & 1,2 & NS \\
\hline Átlag (4) & 2,05 & 0,28 & 1,79 & 0,35 & 0,21 & 95 & 15,3 & 7,6 & 136 \\
\hline \multicolumn{10}{|c|}{2006} \\
\hline 0 & 1,65 & 0,34 & 2,16 & 0,43 & 0,19 & 77 & 15,0 & 7,1 & 149 \\
\hline 80 & 1,73 & 0,31 & 2,17 & 0,43 & 0,19 & 89 & 16,3 & 7,2 & 154 \\
\hline 160 & 2,05 & 0,32 & 2,19 & 0,45 & 0,21 & 110 & 17,7 & 7,8 & 177 \\
\hline 240 & 2,30 & 0,31 & 2,21 & 0,48 & 0,20 & 127 & 19,9 & 8,7 & 180 \\
\hline $\mathrm{SzD}_{5 \%}(3)$ & 0,12 & 0,02 & NS & 0,04 & NS & 15 & 1,9 & 0,7 & 23 \\
\hline Átlag (4) & 1,93 & 0,32 & 2,18 & 0,45 & 0,20 & 101 & 17,2 & 7,7 & 168 \\
\hline \multicolumn{10}{|c|}{2007} \\
\hline 0 & 2,57 & 0,32 & 2,47 & 0,46 & 0,25 & 57 & 27,4 & 8,9 & 153 \\
\hline 80 & 2,65 & 0,32 & 2,47 & 0,48 & 0,25 & 66 & 26,5 & 8,8 & 153 \\
\hline 160 & 2,68 & 0,31 & 2,45 & 0,47 & 0,26 & 71 & 26,4 & 8,7 & 160 \\
\hline 240 & 2,77 & 0,31 & 2,48 & 0,47 & 0,25 & 80 & 24,9 & 8,7 & 153 \\
\hline $\mathrm{SzD}_{5 \%}(3)$ & 0,07 & NS & NS & NS & NS & 12 & NS & NS & NS \\
\hline Átlag (4) & 2,67 & 0,31 & 2,47 & 0,47 & 0,25 & 68 & 26,3 & 8,8 & 156 \\
\hline \multicolumn{10}{|c|}{2008} \\
\hline 0 & 2,13 & 0,22 & 2,19 & 0,43 & 0,18 & 37 & 13,0 & 5,3 & 115 \\
\hline 80 & 2,78 & 0,25 & 2,17 & 0,43 & 0,21 & 53 & 14,8 & 6,5 & 131 \\
\hline 160 & 2,93 & 0,27 & 2,17 & 0,43 & 0,23 & 63 & 15,3 & 6,8 & 133 \\
\hline 240 & 2,98 & 0,26 & 2,11 & 0,45 & 0,24 & 69 & 15,0 & 6,8 & 136 \\
\hline $\mathrm{SzD}_{5 \%}$ (3) & 0,16 & 0,02 & NS & NS & 0,06 & 7 & 1,4 & 0,4 & 13 \\
\hline Átlag (4) & 2,70 & 0,25 & 2,16 & 0,44 & 0,22 & 55 & 14,5 & 6,4 & 129 \\
\hline
\end{tabular}

Table 5. The effect of $\mathrm{N}$ fertilisation on the nutrient concentration of maize leaves at the beginning of tasseling (Szarvas 2005-2008). (1) N dose ( $\mathrm{kg} \mathrm{ha}^{-1}$ ), (2) Nutrient concentration, (3) LSD ${ }_{5 \%}$, (4) Mean. 
A kukorica levél címerhányás kezdetén mért N-koncentrációja és a szemtermés közötti összefüggés alapján a kielégítő N-ellátottsági határérték a maximális szemtermés 95\%-os szintjén 2,0-3,2\% a 2002 és 2008 közötti kísérleti években (2. ábra). A 2001-es kísérleti évben a levél N-koncentrációja jelentôsen eltért a többi vizsgálati évtốl, így azt külön értékeltük. Ebben az évben a kielégítô N-koncentráció 3,5-4,8\% volt, azonban 4\% N-tartalom felett már további szignifikáns terméshozam növekedés nem volt kimutatható (2. ábra).

2. ábra. Kapcsolat a kukorica levél N-koncentrációja és a szemtermés között (Szarvas 2001; 2002-2008)
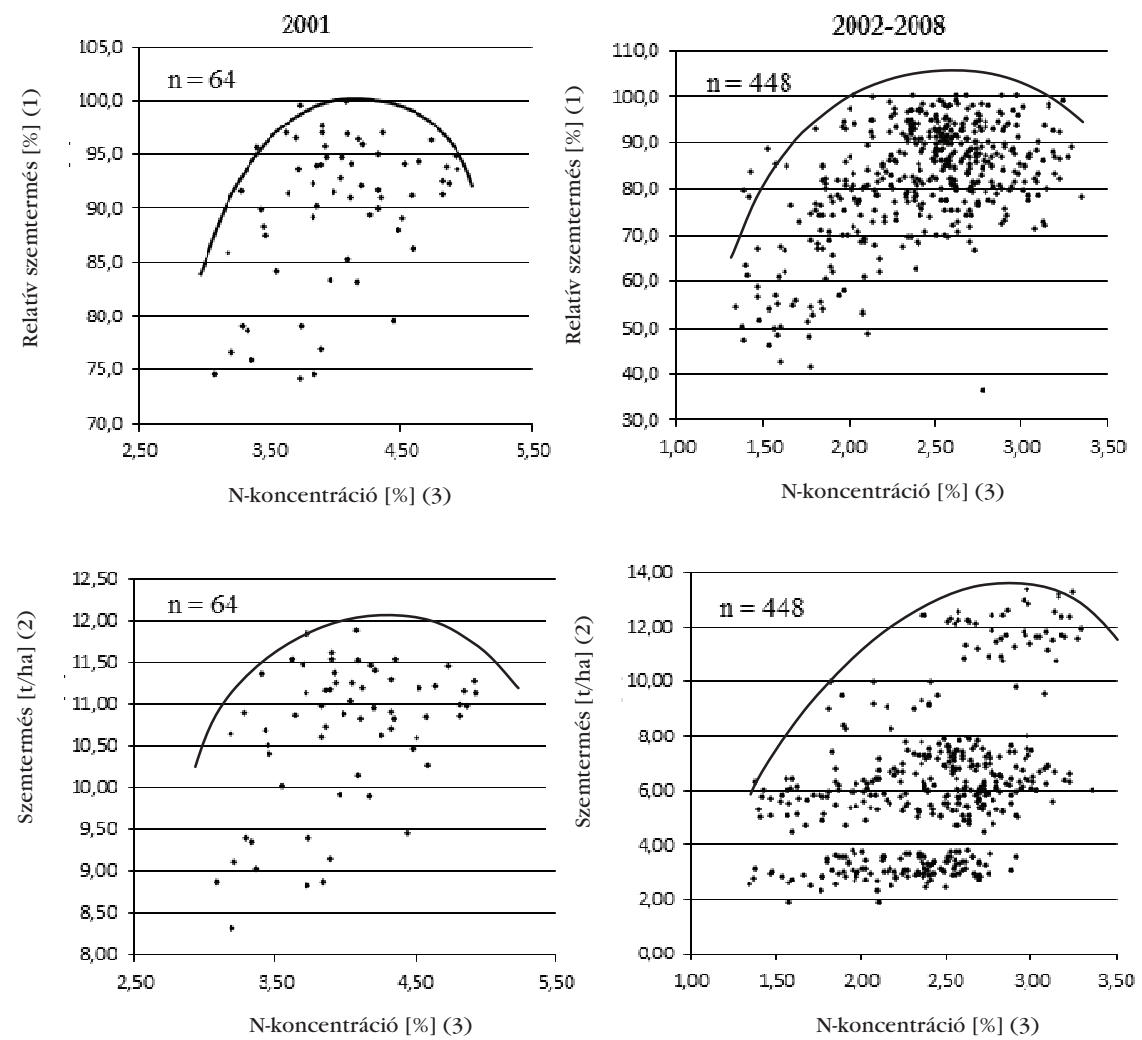

Figure 2. Correlation between the N concentration of maize leaves and grain yield (Szarvas 2001; 2002-2008). (1) Relative grain yield [\%], (2) Grain yield [t/ha], (3) N concentration [\%].

A kukorica kielégítô N-ellátottságára több szerző is közöl adatokat a címerhányás idôszakára, a csôvel szembeni levélre vonatkoztatva. Például a címer- 
hányás kezdetére Jones (1967) 2,5-3,5\%, Kádár és Elek (1980), valamint Kádár (1992) 2,5-4,0\%, még Reuter és Robinson (1997) 3,4\% N-koncentrációban adja meg a kielégítő ellátottság határértékét. A teljes címerhányásban a N-ellátottsági határértékek már kissé alacsonyabbak. Reuter és Robinson (1997) közlése szerint 2,5-3,0\%, még Chapman (1967) szerint 2,4-3,7\%. Kísérleti eredményeinket összehasonlítva a korábbi vizsgálatok kielégítő N-koncentráció határértékeivel megállapítható, hogy azok kissé alacsonyabbak a hét vizsgálati év vonatkozásában. Több évben is kimutatható volt, hogy a címerhányás kezdetén mért $2 \%$ körüli N-koncentráció kielégító volt, mintegy 9-10 t/ha-os szemterméssel párosult. Nyolc kísérleti év nagy adatbázisa alapján megállapítható, hogy 10-14 t/ha-os szemtermés eléréséhez a kielégítő N-koncentráció határérték a kukorica címerhányásának kezdetén 2,0-4,0\% közötti értékben határozható meg. Valószínûsíthető, hogy a kielégítő N-ellátottság kisebb alsó értéke részben összefügg azzal, hogy a mai hibridek területegységre esô szárazanyag-produkciója nagyobb, fehérjetartalmuk kisebb, fajlagos N-felhasználásuk mérsékeltebb. Az, hogy a kielégítô N-ellátottsági határérték viszonylag tág intervallumban változik, részben befolyásolja az is, hogy a növény $\mathrm{N}$-felvételét nemcsak a talaj $\mathrm{N}$ szolgáltatása szabályozza, hanem a kukorica hibridek növekedési rátája is (Berzsenyi és Lap 2000, Berzsenyi 2009).

A kísérleti periódus alatt vizsgáltuk a N-trágyázás hatását a kukorica levél tápelem-összetételére, valamint a levél N-koncentrációjának kölcsönhatását a többi tápelem koncentrációjával.

A kukorica levél P-tartalma 0,22-0,35\% között változott, melyet a N-trágyázás négy kísérleti évben statisztikailag igazolhatóan nem befolyásolt, két évben (2002, 2008) azt szignifikánsan növelte, míg két évben (2005, 2006) csökkentette (4. és 5. táblázat). Több szerző (Kádár 1988, Kincses et al. 2002, Szalókiné és Szalóki 2002) arról számol be, hogy a N-trágyázás a kukorica P-tartalmát érdemben nem befolyásolja. Ettől eltérő eredményekről számol be Debreczeni és Debreczeniné (1983), miszerint a N-trágyázás a P-koncentrációt a szárban csökkenti, a növény többi részében növeli. Mengel (1976) rámutat arra, hogy a N-ellátás formája $\left(\mathrm{NH}_{4+}\right.$ vagy $\mathrm{NO}_{3-}$ ) és a talaj pH-viszonyai is jelentôsen befolyásolhatják az ásványi anyagok felvételét. $\mathrm{A} \mathrm{NO}_{3}-\mathrm{N}$ táplálás, savanyú talajokon a $\mathrm{NO}_{3}$-N jobb felvehetôsége növeli a kation-felvételt és mérsékli az anion (többek között a foszfát) felvételt. Kísérletünkben ammónium-nitrát formájában jutattuk ki a N-t, és a talaj pH-ja savanyú $(5,0-5,2)$ volt, ami a $\mathrm{NO}_{3}$-N-felvételnek kedvezőbb az $\mathrm{NH}_{4}$-N-el szemben. Ennek tanulmányozására 2005-ben 
és 2006-ban vizsgáltuk a talaj 0-60 cm-es rétegének ásványi $\mathrm{N}$-tartalmát $\left(\mathrm{NO}_{3}-\mathrm{N}\right.$, $\mathrm{NH}_{4}-\mathrm{N}$ ) a tenyészidố alatt (6. táblázat). A kukorica címerhányása, így a levél mintavétele június végére és július első dekádjára esett. Amennyiben a címerhányás elốtti, intenzív növekedési és $\mathrm{N}$-felvételi periódus talaj ásványi-N formáinak változását vizsgáljuk, kitúnik, hogy a mineralizációt, az ammonifikációt kísérốn az $\mathrm{NH}_{4}-\mathrm{N}$ mennyisége növekedett, míg az $\mathrm{NO}_{3}-\mathrm{N}$ mennyisége jelentôsen csökkent. A kukorica címerhányás elốtti intenzív $\mathrm{NO}_{3}$-N-felvétele részben magyarázhatja a vizsgált két évben a levél P-koncentrációjának csökkenését.

A kukorica levél N- és P-koncentrációja közötti kölcsönhatást vizsgálva megállapítható, hogy 2002-ben és 2008-ban szoros pozitív ( $\mathrm{r}=0,84$ és 0,85$)$ korreláció volt kimutatható, míg 2005-ben és 2006-ban közepes negatív ( $\mathrm{r}=-0,44$ és -0,63) korreláció (3. ábra). Annak ellenére, hogy a N-trágyázás egyes években a levél P-koncentrációját csökkentette illetve növelte, a P-koncentráció minden esetben a kielégítő, 0,25-0,50\% (Kádár 1992, Izsáki 2008b) ellátottsági tartományban maradt.

A nyolc éves kísérleti ciklusban a kukorica levél K-koncentrációja 1,732,55\% között változott, melyet a N-ellátottság megbízhatóan nem befolyásolt, hanem elsősorban az évjárat (4. és 5. táblázat).

A címerhányás kezdetén a kukorica levél Ca-koncentrációja 0,27-0,54\% között változott a vizsgálati periódus alatt. Az évjárat nagyobb mértékben befolyásolta a Ca-tartalmat, mint a N-trágyázás. A jobb N-ellátottság két évben $(2005,2006)$ szignifikánsan növelte a Ca-koncentrációt, még a többi évben csak tendencia jelleggel érvényesült a N-trágyázás pozitív hatása (4. és 5. táblázat). A levél N- és Ca-koncentrációja között 2005-ben közepes $(\mathrm{r}=0,67)$, 2006-ban szoros $(\mathrm{r}=0,89)$ pozitív korrelációt tapasztaltunk (4. ábra).

A Mg-koncentráció a kukorica levélben 0,18-0,37\% tartományban mozgott a címerhányás kezdetén. A N-trágyázás szignifikáns Mg-koncentráció növelô hatása a két legnagyobb terméshozamú évben $(2005,2008)$ volt kimutatható, amikor a levél $\mathrm{N}$ - és Mg-koncentrációja között szoros $(\mathrm{r}=0,82)$ illetve közepes $(\mathrm{r}=0,56)$ pozitív korreláció érvényesült (4. és 5. táblázat, 5. ábra).

A mikroelemek közül a levél Mn-tartalma mutatott legegyértelmúbb összefüggést a N-ellátottsággal. Minden kísérleti évben érvényesült, hogy a N-trágyázás növekvó adagja a Mn-koncentrációt fokozatosan emelte. A N-ellátottságtól és az évjárattól függóen a Mn-koncentráció tág intervallumban (37-159mg/kg) változott. A N- és Mn-koncentráció között minden évben szoros pozitív korreláció mutatkozott (4. és 5. táblázat, 6. ábra). 
6. táblázat. A talaj ásványi N-tartalmának tenyészidô alatti változása különbözó N-ellátottsági szinten, $N(\mathrm{~kg} / \mathrm{ha}$ ) a 0-60 cm-es talajrétegben (Szarvas 2005-2006)

\begin{tabular}{|c|c|c|c|c|}
\hline \multirow{2}{*}{$\begin{array}{l}\mathbf{N}_{\min } \\
(1)\end{array}$} & \multicolumn{4}{|c|}{$\begin{array}{c}\text { Nitrogén adag }(\mathrm{kg} / \mathrm{ha}) \\
\text { (2) }\end{array}$} \\
\hline & 0 & 80 & 160 & 240 \\
\hline \multicolumn{5}{|c|}{2005.04 .15}$. \\
\hline $\mathrm{NH}_{4}-\mathrm{N}$ & 22,0 & 25,0 & 26,0 & 32,0 \\
\hline $\mathrm{NO}_{3}-\mathrm{N}$ & 28,0 & 49,0 & 85,0 & 97,0 \\
\hline Összes $N_{\min }(3)$ & 50,0 & 74,0 & 111,0 & 129,0 \\
\hline \multicolumn{5}{|c|}{ 2005.05. 10 . } \\
\hline $\mathrm{NH}_{4}-\mathrm{N}$ & 30,7 & 35,2 & 34,2 & 45,7 \\
\hline $\mathrm{NO}_{3}-\mathrm{N}$ & 26,8 & 49,5 & 78,2 & 89,5 \\
\hline Összes $\mathbf{N}_{\min }(3)$ & 57,5 & 84,7 & 112,4 & 135,2 \\
\hline \multicolumn{5}{|c|}{2005.06 .07}$. \\
\hline $\mathrm{NH}_{4}-\mathrm{N}$ & 56,6 & 63,6 & 69,2 & 68,2 \\
\hline $\mathrm{NO}_{3}-\mathrm{N}$ & 11,2 & 28,4 & 37,2 & 59,5 \\
\hline Összes $N_{\min }(3)$ & 67,8 & 92,0 & 106,4 & 127,7 \\
\hline \multicolumn{5}{|c|}{2005.07 .06}$. \\
\hline $\mathrm{NH}_{4}-\mathrm{N}$ & 47,0 & 58,3 & 69,8 & 66,1 \\
\hline $\mathrm{NO}_{3}-\mathrm{N}$ & 7,5 & 7,5 & 9,7 & 16,1 \\
\hline Összes $N_{\min }(3)$ & 54,5 & 65,8 & 79,5 & 82,2 \\
\hline \multicolumn{5}{|c|}{2005.08 .09}$. \\
\hline $\mathrm{NH}_{4}-\mathrm{N}$ & 52,7 & 50,9 & 72,4 & 83,7 \\
\hline $\mathrm{NO}_{3}-\mathrm{N}$ & 5,7 & 7,9 & 7,9 & 10,4 \\
\hline Összes $\mathbf{N}_{\min }$ (3) & 58,4 & 58,8 & 80,3 & 94,1 \\
\hline \multicolumn{5}{|c|}{2005.09 .06}$. \\
\hline $\mathrm{NH}_{4}-\mathrm{N}$ & 33,5 & 35,1 & 31,0 & 39,1 \\
\hline $\mathrm{NO}_{3}-\mathrm{N}$ & 10,6 & 12,0 & 12,6 & 13,0 \\
\hline Összes $N_{\min }(3)$ & 44,1 & 47,1 & 43,6 & 52,1 \\
\hline \multicolumn{5}{|c|}{2006.04 .15} \\
\hline $\mathrm{NH}_{4}-\mathrm{N}$ & 23,5 & 27,2 & 30,5 & 31,6 \\
\hline $\mathrm{NO}_{3}-\mathrm{N}$ & 40,8 & 58,9 & 90,7 & 121,8 \\
\hline Összes $\mathbf{N}_{\min }(3)$ & 64,3 & 86,1 & 121,2 & 153,4 \\
\hline
\end{tabular}

A 6. táblázat folytatása a következố oldalon... 
A 6. táblázat folytatása...

\begin{tabular}{|c|c|c|c|c|}
\hline \multirow{2}{*}{$\begin{array}{l}\mathrm{N}_{\text {min }} \\
\text { (1) }\end{array}$} & $(2)$ & \multicolumn{2}{|c|}{ Nitrogén adag (kg/ha) } & \\
\hline & 0 & 80 & 160 & 240 \\
\hline \multicolumn{5}{|c|}{2006.05 .24}$. \\
\hline $\mathrm{NH}_{4}-\mathrm{N}$ & 31,6 & 33,7 & 37,4 & 37,6 \\
\hline $\mathrm{NO}_{3}-\mathrm{N}$ & 32,5 & 52,3 & 83,6 & 111,7 \\
\hline Összes $\mathbf{N}_{\min }(3)$ & 64,1 & 86,0 & 121,0 & 149,3 \\
\hline \multicolumn{5}{|c|}{2006.06 .28}$. \\
\hline $\mathrm{NH}_{4}-\mathrm{N}$ & 79,1 & 105,6 & 102,0 & 117,7 \\
\hline $\mathrm{NO}_{3}-\mathrm{N}$ & 14,8 & 21,8 & 21,5 & 26,4 \\
\hline Összes $N_{\min }(3)$ & 93,9 & 127,4 & 123,5 & 144,1 \\
\hline \multicolumn{5}{|c|}{2006.07 .27}$. \\
\hline $\mathrm{NH}_{4}-\mathrm{N}$ & 26,9 & 33,4 & 46,7 & 48,8 \\
\hline $\mathrm{NO}_{3}-\mathrm{N}$ & 9,8 & 15,6 & 15,0 & 20,7 \\
\hline Összes $\mathbf{N}_{\min }(3)$ & 36,7 & 49,0 & 61,7 & 69,5 \\
\hline \multicolumn{5}{|c|}{2006.09 .04}$. \\
\hline $\mathrm{NH}_{4}-\mathrm{N}$ & 16,8 & 19,8 & 23,1 & 25,7 \\
\hline $\mathrm{NO}_{3}-\mathrm{N}$ & 15,6 & 14,6 & 15,5 & 16,1 \\
\hline Összes $\mathbf{N}_{\min }(3)$ & 32,4 & 34,4 & 38,6 & 41,8 \\
\hline \multicolumn{5}{|c|}{2006.10 .16}$. \\
\hline $\mathrm{NH}_{4}-\mathrm{N}$ & 22,6 & 24,2 & 30,5 & 31,7 \\
\hline $\mathrm{NO}_{3}-\mathrm{N}$ & 13,0 & 14,6 & 16,2 & 20,5 \\
\hline Összes $N_{\min }(3)$ & 35,6 & 38,8 & 46,7 & 52,2 \\
\hline
\end{tabular}

Table 6. Change in the mineral $\mathrm{N}$ concent of soil over the growing season on different levels of $\mathrm{N}$ supply, $\mathrm{N}\left(\mathrm{kg} \mathrm{ha}^{-1}\right)$ in the 0-60 cm soil layer (Szarvas 2005-2006). (1) Mineral N, (2) N dose ( $\left.\mathrm{kg} \mathrm{ha}^{-1}\right)$, (3) Total mineral $\mathrm{N}$.

A levél Zn-tartalmát a N-trágyázás három kísérleti évben (2002, 2006, 2008) megbízhatóan növelte, míg a rendkívül száraz 2003-as évben csökkentette. Ezen években a levél $\mathrm{N}$ - és Zn-koncentrációja között a pozitív ( $\mathrm{r}=0,53-0,83)$ illetve a negatív $(\mathrm{r}=-0,77)$ korreláció is kimutatható volt. Az évjárattól és a N-ellátottságtól függóen a Zn-koncentráció $13-28$ mg/kg között változott (4. és 5. táblázat, 7. ábra). 
3. ábra. Összefüggés a kukorica levél $N$ - és P-tartalma között

(Szarvas 2002, 2008; 2005, 2006)
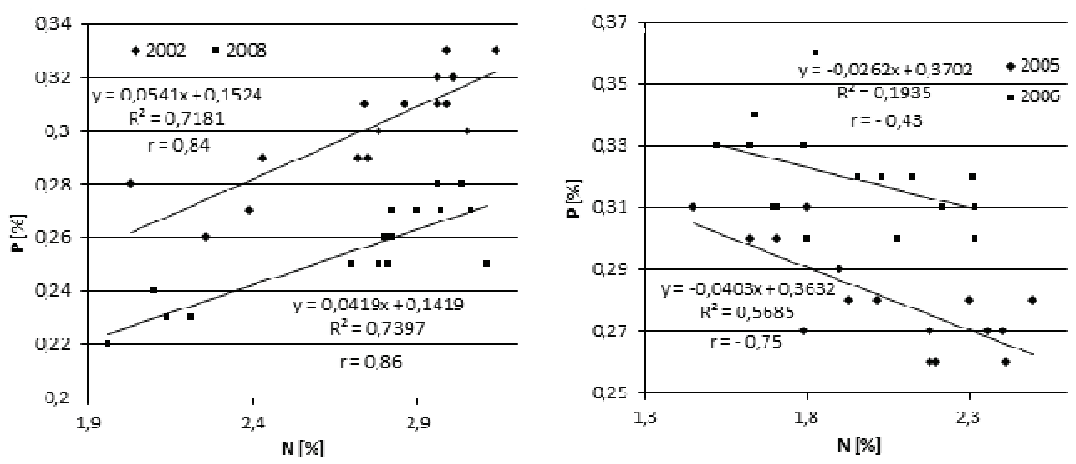

Figure 3. Correlation between the N and P content of maize leaves (Szarvas 2002, 2008; 2005, 2006).

4. ábra. Összefüggés a kukorica levél $N$ - és Ca-tartalma között (Szarvas 2005, 2006)

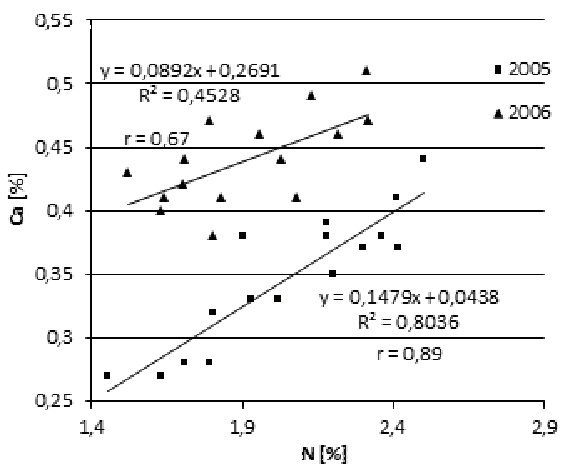

Figure 4. Correlation between the $\mathrm{N}$ and Ca content of maize leaves (Szarvas 2005, 2006). 
5. ábra. Összefüggés a kukorica levél $N$-és Mg-tartalma között (Szarvas 2005, 2006)

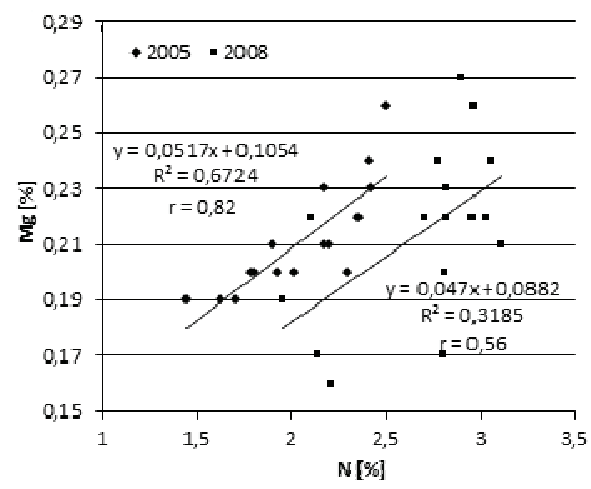

Figure 5. Correlation between the N and Mg content of maize leaves (Szarvas 2005, 2006).

6. ábra. Összefüggés a kukorica levél $N$-és Mn-tartalma között

(Szarvas 2002, 2004, 2006, 2008)
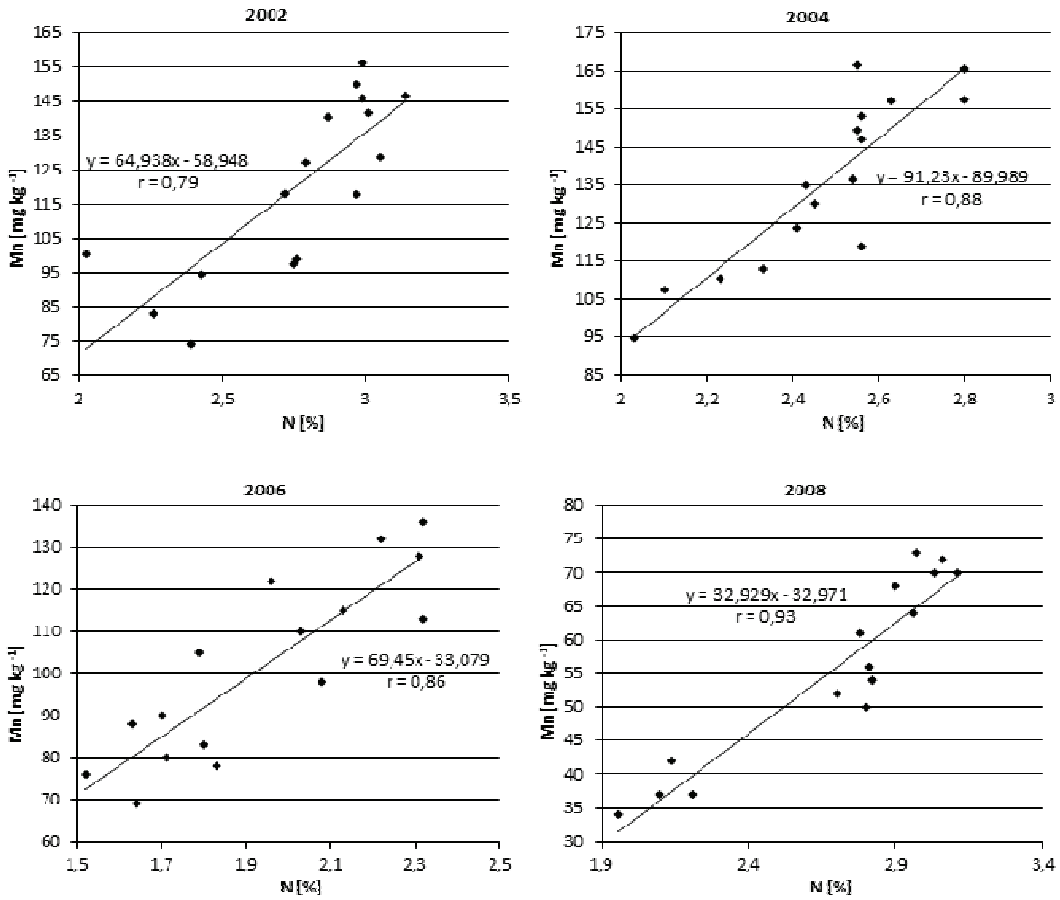

Figure 6. Correlation between the N and Mn content of maize leaves (Szarvas 2002, 2004, 2006, 2008). 
7. ábra. Összefüggés a kukorica levél $N$ - és Zn-tartalma között

(Szarvas 2002, 2006, 2008; 2003)
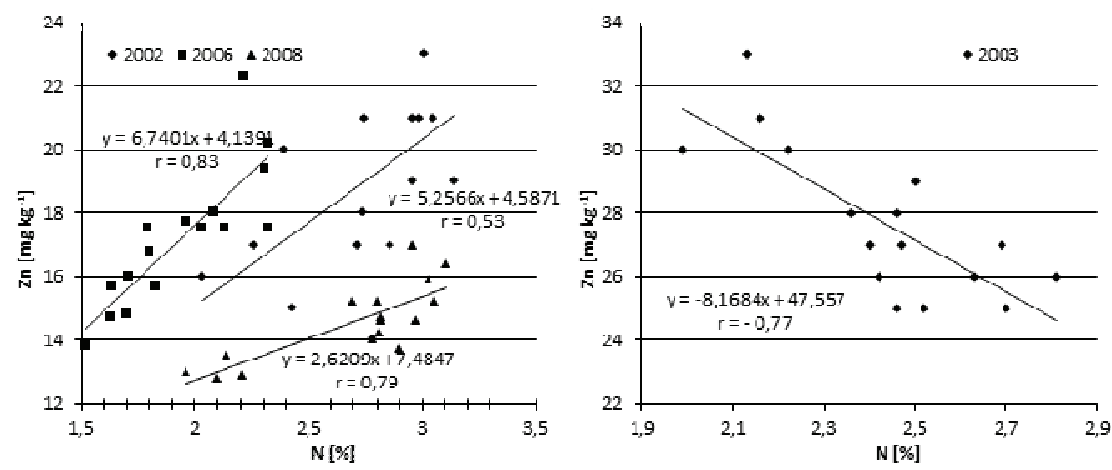

Figure 7. Correlation between the N and Zn content of maize leaves (Szarvas 2002, 2006, 2008; 2003).

A N-trágyázás a levél Cu-koncentrációját három évben (2005, 2006, 2008) szignifikánsan növelte, és szoros pozitív korreláció $(r=0,72-0,95)$ volt kimutatható a N- és Cu-koncentráció között. A Cu-koncentráció 3,4-8,9 mg/kg között változott a N-ellátottságtól és az évjárattól függóen. Az évjárat Cu-tartalmat befolyásoló hatása kifejezettebb, mint a N-ellátottságé (4. és 5. táblázat, 8. ábra).

A levél Fe-tartalmát a jobb N-ellátottság minden évben növelte, de szignifikáns koncentráció növekedést csak 2006-ban és 2008-ban tapasztaltunk. E két évben a levél N-és Fe-koncentrációja között pozitív kölcsönhatás ( $r=0,68,0,80)$ érvényesült. A kísérleti periódus alatt a levél Fe-koncentrációja 82-225 mg/kg intervallumban változott (4. és 5. táblázat, 9. ábra).

Kádár és Elek (1980), Kádár (1992), Reuter és Robinson (1997), valamint Izsáki (2005) közlése szerint a kukorica kielégítő tápelem-ellátottsági határértékei a címerhányás kezdetén a levél tápelem-koncentrációja alapján a következők: Ca-ból 0,15-1,00\%, Mg-ból 0,10-1,00\%, Mn-ból 20-200 mg/kg, Zn-ből 10-100 mg/kg, Cu-ből 3-20 mg/kg és Fe-ból 20-250 mg/kg. Kísérleti eredményeinket összehasonlítva a publikált tápelem-ellátottsági határértékekkel megállapítható, hogy a N-trágyázás által kiváltott tápelem-koncentráció változások ellenére minden tápelem koncentrációja a kielégítő ellátottsági tartományban maradt a kísérletek körülményei között. 
8. ábra. Összefüggés a kukorica levél $N$-és Cu-tartalma között (Szarvas 2005, 2006, 2008)

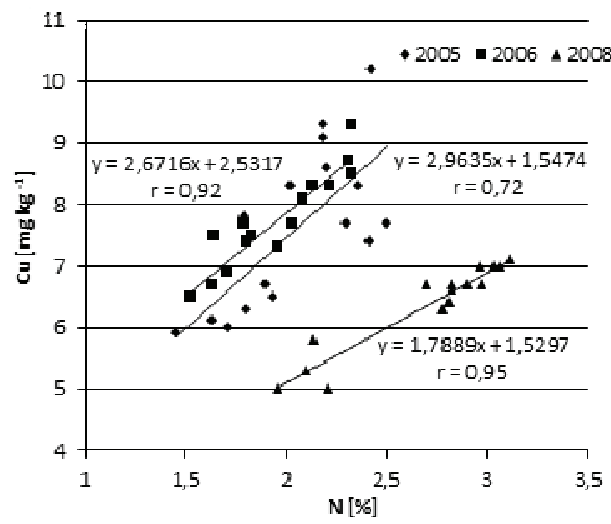

Figure 8. Correlation between the $\mathrm{N}$ and Cu content of maize leaves (Szarvas 2005, 2006, 2008).

9. ábra. Összefüggés a kukorica levél $N$ - és Fe-tartalma között

(Szarvas 2006, 2008)

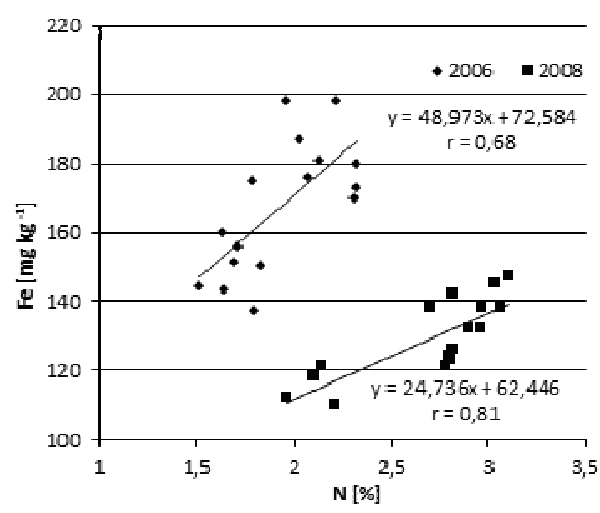

Figure 9. Correlation between the N and Fe content of maize leaves (Szarvas 2006, 2008). 


\section{Köszönetnyilvánítás}

A kutatás részben az OTKA (T-020578, T-034436 és T-048816) támogatásával valósult meg.

\section{IRODALOM}

Bergmann, W.-Neubert, P.: 1976. Pflanzendiagnose und Pflanzenanalyse. Jena, Germany. VEB Gustav Fisher Verlag.

Chapman, H. D.: 1967. Plant analysis values suggestive of nutrient status of selected crops. [In: R. C. Dinauer (ed.) Soil testing and plant analysis, part II: Plant analysis.] Madison. Wisc. SSSA. 77-92.

Berzsenyi Z.: 1993. A N-mútrágyázás és az évjárat hatása a kukorica hibridek (Zea mays L.) szemtermésére és a N-mútrágya reakciójára tartamkísérletben az 1970-1991. években. Növénytermelés. 42. 1: 49-63.

Berzsenyi Z.: 2009. A nitrogén mútrágyázás hatásának vizsgálata a kukorica (Zea mays L.) hibridek növekedésére Richards-függvénnyel. Növénytermelés. 58. 1: 5-21.

Berzsenyi Z.-Lap, O. Q.: 2000. Különböző tenyészidejú kukorica (Zea mays L.) hibridek növekedésének jellemzése Richards-függvénnyel eltéró évjáratokban. Növénytermelés. 49. 1-2: 95-116.

Debreczeni B.-Debreczeni B.-né: 1983. A tápanyag- és vízellátás kapcsolata. Mezőgazdasági Kiadó. Budapest.

Csathó, P.: 1998. Correlations between two soil extractants and corn leaf potassium contents from Hungarian field trails. Commun. Soil Sci. Plant Anal. 29: 2149-2160.

Izsáki Z.: 2000. A diagnosztikai célú növényanalízis alkalmazása a cukorrépa tápanyagellátásának rendszerében. Cukoripar. 53. 4: 141-147.

Izsáki, Z.: 2004. Evaluation of grain quality of maize at different nutrient supply levels. [In: Jacobsen S. E. et al. (eds.) Proceedings of the VIII ESA Congress: European Agriculture in a global context.] Copenhagen. Denmark. KVL. 521-522.

Izsáki, Z.: 2005. Limit value of nutritional status of maize (Zea mays L.) for plant analysis. Cereal Res. Commun. 33. 1: 101-104.

Izsáki Z.: 2008a. Hatások és kölcsönhatások vizsgálata NPK mútrágyázási tartamkísérletben kukorica (Zea mays L.) jelzônövénnyel. Növénytermelés. 57. 3: 275-289.

Izsáki, Z.: 2008b. Effect of soil P supply on P-Zn interactions in a maize (Zea mays L.) long-termfield experiment. Cereal Res. Commun. 36: 1851-1854.

Izsáki, Z.: 2009. Effect of nitrogen supply on nutritional status of maize. Commun. Soil Sci. Plant Anal. 40: 960-973. 
Izsáki, Z.: 2010a. Nutritional status of maize (Zea mays L.) in early development stage. Növénytermelés. 59. 4: 445-448.

Izsáki Z.: 2010b. A N-mútrágyázás hatása a csernozjom réti talaj nitrogénmérlegére és a $\mathrm{NO}_{3}$-N mélységi eloszlására 1990-2007 között. Agrokémia és Talajtan. 59. 2: 233-248.

Jones, J. B.: 1967. Integration of plant analysis for several agronomic crops. [In: Dinauer R. C. (ed.) Soil testing and plant analysis, part II: Plant analysis.] Madison. Wisc. SSSA. 49-58.

Kádár I.: 1988. A meszezés és mútrágyázás együttes hatásának vizsgálata tenyészedénykísérletben. II. Növényvizsgálati és tápanyagforgalmi elemzések. Agrokémia és Talajtan. 36-37: 239-252.

Kádár I.: 1992. A növénytáplálás alapelvei és módszere. Magyar Tudományos Akadémia Talajtani és Agrokémiai Kutató Intézete. Budapest.

Kádár I.: 2008. Kölcsönhatások vizsgálata a növénytáplálási kutatásokban. Talajvédelem különszám. Talajtani vándorgyúlés. 2008. május 28-29. Nyíregyháza. 265-274.

Kádár I.-Elek É.: 1980. Állókultúrák és szántóföldi növények mintavételi módszere. Budapest. MÉM NAK.

Kincses S.-né-Filep T.-Loch J.: 2002. Az NPK-trágyázás hatása a kukorica tápelem-felvételének dinamikájára, öntözött és nem öntözött viszonyok között. Acta Agraria Debreceniencis. 1: 1-5.

Lemaire, G. (ed.): 1997. Diagnostic of the nitrogen status in crops. Heidelberg. Germany. Springer Verlag.

Lente A.-Pepó P.: 2009. Az évjárat és néhány agrotechnikai tényezó hatása a kukorica termésére csernozjom talajon. Növénytermelés. 58. 1: 39-51.

Mengel K.: 1976. A növények táplálkozása és anyagcseréje. Mezőgazdasági Kiadó. Budapest.

MÉM NAK: 1979. Mútrágyázási irányelvek és üzemi számítási módszer. Budapest.

Nagy J.-Huzsvai L.: 1995. Az évjárat hatás értékelése a kukorica (Zea mays L.) termésére. Növénytermelés. 44. 4: 385-393.

Nagy, J.: 2007: Evaluating the effect of year and fertilisation on the yield of mid ripering (FAO 400-499) maize hibrids. Cereal Res. Commun. 35. 3: 515-517.

Pepó P.: 2009. A kukorica (Zea mays L.) termése és növénydőlése száraz és csapadékos évjáratban csernozjom talajon. Növénytermelés. 58. 3: 53-66.

Plénet, D.-Cruz, P.: 1997. Maize and sorghum. [In: Lemaire, G. (ed.) Diagnosis of the nitrogen status in crops.] Heidelberg. Germany. Springer Verlag. 93-106.

Reuter, D. J.-Robinson, J. B.: 1997. Plant analysis: An interpretation manual. Collingwood. Australia. CSIRO.

Sárvári M.-Szabó P.: 1998. A termesztési tényezők hatása a kukorica termésére. Növénytermelés. 47. 2: 213-221. 
Smith, F. W.-Loneragan, J. F.: 1997. Interpretation of plant analysis: Concept and principles. [In: Reuter, D. J.-Robinson, J. B. (eds.) Plant analysis: An interpretation manual.] Collingwood. Ausztralia. CSIRO. 1-33.

Szalókiné Z. I.-Szalóki S.: 2002. A víz- és a tápanyag-ellátás hatása a kukorica termésösszetevőinek mennyiségére és NPK-tartalmára. Növénytemelés. 51. 5: 543-557.

A szerzó levelezési címe - Address of the author:

Dr. Izsáki Zoltán

Szent István Egyetem

Víz- és Környezetgazdálkodási Kar

Szarvas

Szabadság út 1-3.

H-5540 